Radmila Bjekić ${ }^{1}$

University of Novi Sad, Faculty of Economics

Marijana Rodić ${ }^{2}$

Gender Equality Institute, NoviSad, Republic of Serbia

Marko Aleksić3

Dimitrije Gašić ${ }^{4}$

University of Novi Sad, Faculty of Economics
ORIGINAL SCIENTIFIC ARTICLE

DOI: 10.5937/ekonomika2102047B

Received: October, 24. 2020.

Accepted: January, 18. 2021.

\title{
RELATIONSHIP BETWEEN SOCIAL COMPETENCES OF MANAGER AND LEADERSHIP OUTCOMES
}

\begin{abstract}
In today's turbulent business environment, acquiring and developing leadership skills is one of the key challenges for managers, and emotional and social competencies are predominat among such skills. Possession of this specific set of competencies is a key factor necessary for building positive psychological climate in an organization. The subject of the paper is the analysis of social competencies of manager, particularly social awareness (empathy and organizational awareness) and relationship management (conflict management,coach and mentor, influence, inspirational leadership and teamwork), as well as the analysis of leadership outcomes manifested through perceived leadership effectiveness by the employees, employee satisfaction with immediate superiors and encouraging employees by managers to put an extra effort into doing their job. The aim of this paper is to determine the relationship between social competencies of manager and the outcomes of leadership. The research was conducted on a sample of 30 employees in 8 organizations with more than 50 employees. Standardized ESCI (Emotional and Social Competency Inventory) and MLQ (Multifactor Leadership Questionnaire) questionnaires were used for the purpose of the research. Data analysis was performed using Spearman rank correlation and standard multiple regression. SPSS 25.0 software was used for data processing. A limitation of the study is the sample size.
\end{abstract}

Key words: managers, social competencies, leadership outcomes, employees

JEL classification: $M 12$

\section{ПОВЕЗАНОСТ СОЦИЈАЛНИХ КОМПЕТЕНЦИЈА МЕНАЏЕРА И ИСХОДА ЛИДЕРСТВА}

\begin{abstract}
Апстракт
У савременим турбулентним условима пословања, стицање и развој лидерских вештина за менауере представља један од кључних изазова, међу којима се доминантно издвајају емочионалне и соиијалне компетениије. Поседовање овог
\end{abstract}

\footnotetext{
${ }^{1}$ radmila.bjekic@ef.uns.ac.rs, ORCID ID: 0000-0002-7263-8025

${ }^{2}$ rodic.marijana@gmail.com, ORCID ID: 0000-0002-5930-8208

${ }^{3}$ marko.aleksic@ef.uns.ac.rs, ORCID ID: 0000-0002-4488-4472

${ }^{4}$ dimitrijegasic33@gmail.com, ORCID ID: 0000-0002-9068-0593
} 
специфичног сета компетенција преставља кључни фактор неопходан за изградюу позитивне психолошке климе у организаичји. Предмет рада је анализа соиијалних компетенција меначера као што су друштвена свест (емаптија и свест о организачији) и управљање односима (управљање конфликтима, усавршавање других, утииај, инспиративно лидерство и тимски рад), као и анализа исхода лидерства који се манифестују кроз перципирану ефективност лидера од стране запослених, задовољство запослених непосреднм надеређеним и подстииање запослених од стране менаиера да уложе додатни труд у обављање свог посла. Циљ рада је утврђивање релација између социјалних компетенција менаиера и исхода лидерства. Истраживање је спроведено на узорку од 30 запослених у 8 организачија са више од 50 запослених. За потребе истаживања коришћени су стандардизовани упитници ESCI (Emotional and Social Competency Inventory) u MLQ (Multifactor Leadership Questionnaire). Анализа података је извриена применом Спиреманове корелације и стандардне вишеструке регресије. За обраду података коришћен је софтвер СПСС 25.0. Ограничење студије представља величина узорка.

Кључне речи: менацери, социјалне компетенције, исходи лидерства, запослени

\section{Introduction}

For many years, the topic of leadership has been in the center of researchers and scientists' attention. In the focus of that researches are managers. That is expected, because one of the basic management roles are interpersonal roles, which is derived from authority and relationship at the manager-employee level (Strugar-Jelača, 2018) and one of the most important of that roles is role of leader. Contemporary business conditions, characterized by a high level of uncertainty, create an increasing need for the development of specific leadership competencies. It is very important to emphasize that there is no one right leadership approach (Berber et al., 2019) and leadership should not be focused on one single position or individual, but on certain characteristics that have to be developed by managers and then by all the members of the organization (Vujić et al., 2019).

In recent years, both in theory and in practice of leadership, the importance of emotional intelligence has been increasingly emphasized. The importance of emotional intelligence as a new type of intelligence was pointed out by Salovey \& Mayer (1990), and the one who popularized the concept of emotional intelligence and pointed out its importance in the sphere of leadership is Daniel Goleman (1995).

Traditional, cognitive approach to business rejected emotions in business, considering them bad and undesirable, as something that prevents rational thinking and prevents effective decision-making (Albrow, 1992). It was considered that business people should be engaged exclusively in achieving business success, i.e. profit, and managers are required to have the same approach to all the employees, not paying attention to individuality, diversity of their employees. Emotions at work, as we have already mentioned, are a sign of weakness, failure, error. Today, understanding personal emotions and those of others, as well as possessing knowledge and skills for managing emotions, is a necessary condition and an important factor for success in management positions.

The aim of this paper is to determine the relationship between social competencies of managers and the outcomes of leadership. Specific goals, as components of the entire 
research area, relate to identifying social competencies of managers, as well as determining the outcome of leadership in the form of perceived effectiveness, employees' satisfaction and leaders encouraging the employees to extra effort.

The paper consists of theoretical and empirical part. The theoretical part will provide an overview of the existing literature and prevailing views in this area, based on which the hypothesis will be set, and the empirical part of the paper will present the results of primary research.

\section{Paper's theoretical foundations The concept of emotional intelligence}

The importance of emotional intelligence as a new form of intelligence was pointed out by Mayer \& Salovey in 1990. Since then, this topic has been intensively researched. Mayer \& Salovey suggest that emotionally intelligent people perceive emotions accurately, understand emotions and their meaning, and know how to manage their own emotions as well as those of others (Mayer et al., 2016).

The concept experienced its expansion after the publication of the book "Emotional Intelligence", by Daniel Goleman in 1995. The author defines emotional intelligence as "a set of emotional skills that allow us to choose the right way to use feelings and affective, instinctive mechanisms in interaction with other people, as well as to understand and improve our own personality" (Goleman, 1997, 317). The same author introduced the concept of emotional intelligence into the sphere of leadership and pointed out the importance of emotional intelligence for a leader (1998).

Emotional intelligence contributes to positive attitudes, behavior and outcomes, implies the application of emotional skills to achieve the desired behavior. In line with the above, it is an essential quality of a successful manager (Cooper, 1997; Goleman, 1998), an important component of communication within the team (Yost and Tucker, 2000), as well as one of the key factors contributing to better employee performance and commitment (Abraham, 1999). Emotional intelligence has become extremely important as a measure to identify potentially effective leaders, and a means to develop necessary leadership skills (Palmer et al., 2001).

In his research, Daniel Goleman discovered that intelligence (IQ) and technical skills are necessary for success, but they are not enough. Comparing technical skills, intelligence, and emotional intelligence led him to conclude that emotional intelligence (EI) is twice as important for jobs at all levels. David McLeland, in his 1996 study conducted on an example of a global food and beverage company, concluded that the best-positioned leaders had a high degree of emotional intelligence (Goleman, 2004). The same author, in a study conducted in 1998, concluded that there is a certain limit to emotional competencies that makes it possible to distinguish exceptional managers from the average ones (McClelland, 1998).

There are three key approaches to emotional intelligence in literature: Emotional intelligence is an ability (Mayer et al, 1997), they believe that emotional intelligence is a form of social intelligence that includes the ability to perceive one's own and others' feelings and emotions and use this information in guiding their own thinking and behavior (Mayer 
and Salovey, 1997, p.27); Emotional intelligence is a dimension of personality (Petrides \& Furnham, 2000; Petrides et al. 2007) The authors Petrides \& Furnham (2000) were the first to propose a distinction between emotional intelligence as ability and as personality characteristic. Unlike the ability approach, which is related to real abilities, emotional intelligence as a dimension of personality should be explored within the framework of personality, more precisely, it implies self-reporting (Petrides \& Furnham, 2001). Emotional intelligence is a competence: it permeates different psychological domains - a mixed model (Goleman; 1995; Bar-On, 1997; Goleman et al., 2004; Boyatzis, 2011) which, besides abilities, also includes non-cognitive features.

\section{Emotional and social competencies}

The notion of emotional intelligence as a set of emotional and social competencies rests on a mixed model developed by Goleman (1995), which was later perfected. Emotional intelligence consists of 12 competencies that are grouped into four clusters: self-awareness, self-management, social awareness, and relationship management. The first two clusters represent emotional competencies, and the other two represent social competencies (Boyatzis, 2019). Emotional competencies are the ability to recognize and understand one's own emotions, and social competencies are the ability to recognize and understand the emotions of others, as well as using such information in order to achieve superior performance (Emmerling \& Boyatzis, 2012).

The instrument widely used to test emotional intelligence (emotional and social competencies), and that was used in this research is a standardized ESCI questionnaire (Emotional and Social Competences Inventory), developed by the consulting organization Hay Group in collaboration with Goleman \& Boyatzis (Hay Group, 2011).

The importance of emotional and social competencies is indicated by Cheriss (2000) who states that $2 / 3$ of the competencies associated with superior performance in the workplace are emotional and social in nature (Cheriss in Seal et al., 2006). Research that focused only on social competencies is rare, despite the obvious importance of these skills in everyday business involving social interactions, which is especially important when it comes to leadership and the relationship between managers and employees in organizations (Riggio, 2010). The importance of possessing social skills for a leader in a modern dynamic business environment is very high. According to Strukan et al. (2019) leadership and change are synonyms. Leaders are increasingly turning to developing high-quality interpersonal relations between the leaders and employees (Strukan et al., 2019), therefore, from authors' point of view, the social skills of leaders are the key factor for achieving good relations between leaders and employees and a necessary condition for creating a climate in which changes are accepted.

\section{Leadership outcomes}

Leadership outcomes are presented through effectiveness, extra effort and satisfaction. Extra effort is presented in the context of leaders' ability to strengthen the desire of their followers to be successful and willing to make an extra effort to achieve more than they think they can and expect, or to realize their potential (Bass \& Avolio, 
1997). When it comes to effectiveness, it should be emphasized that the perception of leaders by followers is important, i.e. whether followers perceive their superiors as effective in achieving goals and representing their interests before a higher authority, as well as whether employees perceive their work group as effective (Bass \& Avolio, 1997; Jelača et al., 2016). Satisfaction is reflected in employees' satisfaction with their superiors and their management methods (Bass \& Avolio, 1997).

In previous research, transformational leaders were mostly associated with positive leadership outcomes (Wang et al., 2011; Sadeghi \& Pihie, 2012; Dabke, 2016). Contributing to this, transformational leaders strive to raise the level of awareness of their followers, promoting moral values and inclusion of emotions, as well as promoting goals that include freedom, justice, equality (Tasić et al., 2020). If managers want to become a transformational leaders, they must be engaged with followers to exert influence, consider employee needs, coach, inspire, and stimulate (Rubin et al., 2005). In line with previous mentioned, many researches show that coaching has an impact on satisfaction with manager (Szabó et al., 2019), than trust in the leader correlate positively with satisfaction with leader (Bartram \& Casimir, 2007). According to Webb (2008) followers are more satisfied and motivated by leaders who possess great energy, high levels of self-confidence, strong beliefs and ideals. Such leaders, exept they ecourage higher level of satisfaction of followers, they are perceived as effective and motivate employees to make additional efforts to realize their potential.

The instrument most used to examine leadership outcomes, and used in this study as well, is the standardized MLQ-5X questionnaire (Multifactor Leadership Questionnaire) (Bass \& Avolio, 2000; Bass \& Avolio, 2004).

\section{Emotional intelligence and leadership outcomes}

Researches that has focused on relationship between emotional intelligence (emotional and social competencies) and leadership outcomes (effectiveness, extra effort, and satisfaction) exist, but not in large number. The results of a study conducted on a sample of 110 top managers have shown that there is a statistically significant positive strong relationship between emotional intelligence and leadership outcomes (extra effort, effectiveness and satisfaction), with the strongest relationship proven between the ability to identify and understand the emotions of others and leadership outcomes (Gardner, 2002). Schaap \& Coetzee (2005) demonstrated positive relationships between emotional intelligence and all three leadership outcomes in a sample of 100 managers.

The authors more often linked emotional intelligence and one of the outcomes of leadership, and most often it was the effectiveness of leaders, and research has proven a positive link between emotional intelligence and leaders' effectiveness (Kerr et al., 2006; Nabih et al., 2016). Effective leaders, in addition to traditional competencies, also have a high level of emotional intelligence. Van Oosten found that there is a positive impact of emotional competencies on leader effectiveness (Van Oosten, 2013), and Guerin et al. found that social skills are predictors of leader effectiveness (Guerin et al., 2011).

Based on the previous review of the literature and the prevailing views, the following hypothesis was set:

H1: Social competencies of manager are positively related to leadership outcomes (extra effort, effectiveness, and satisfaction). 


\section{Methodology}

The research was conducted at the beginning of 2020 on a sample of 30 employees from 8 organizations that have more than 50 employees. Out of the total number of employees, $67 \%$ work in the private sector and $33 \%$ in the public sector. 19 respondents were males and 11 females. The largest number of respondents $(66 \%)$ belonged to the age group 25-44 years. When it comes to education, 8 have completed High school, 4 threeyear Vocational studies, 12 four-year Academic studies and 6 respondants completed Master studies.

The questionnaires used for the research are ESCI (Emotional and Social Competency Inventory) (Hay Group, 2011) and MLQ Questionnaire (Multifactor Leadership Questionnaire) (Avolio \& Bass, 2004). The standardized ESCI questionnaire consists of 68 questions, measuring leaders' emotional intelligence (social and emotional competencies). The issues were grouped into four clusters: self-awareness, selfmanagement, social awareness, and relationship management. The first two clusters relate to emotional competencies and the other two to social competencies (Boyatzis, 2019, p. 10). Out of a total of 68 questions, 38 measure leaders' social competencies, which is the focus of the research. Nine questions from the standardized MLQ questionnaire were used to measure leadership outcomes. A five-point Likert scale was used to evaluate all the responses.

\section{Analysis of research results}

In the first step, reliability of the measurement scales used in the research was checked, and it was determined that the Cronbach's alpha coefficient is 0.905 (social competencies), i.e. 0.935 (leadership outcomes), which indicates that the measurement scales are reliable and appropriate for measuring social competencies of manager and leadership outcome.

Table 1: Spearman correlation $(N=30)$

\begin{tabular}{|c|c|c|c|c|c|}
\hline & & $\mathbf{M}$ & SD & $\begin{array}{c}\text { Social } \\
\text { competences of } \\
\text { manager }\end{array}$ & $\begin{array}{c}\text { Leadership } \\
\text { outcomes }\end{array}$ \\
\hline \multirow{2}{*}{$\begin{array}{l}\text { Social } \\
\text { competences } \\
\text { of manager }\end{array}$} & rho & \multirow{2}{*}{3.6494} & \multirow{2}{*}{.3990} & 1.000 & $.619^{* *}$ \\
\hline & p & & &.- & .000 \\
\hline \multirow{2}{*}{$\begin{array}{l}\text { Leadership } \\
\text { outcomes }\end{array}$} & rho & \multirow{2}{*}{3.8139} & \multirow{2}{*}{.8902} & $.619^{* *}$ & 1.000 \\
\hline & $\mathbf{p}$ & & & .000 & -. \\
\hline
\end{tabular}

Source: Author's calculation

Based on the results shown in Table 1, it can be concluded that there is a strong positive correlation between managers' social competencies (social awareness and 
relationship management $)$ and leadership outcomes $(\mathrm{r}=0.619 ; \mathrm{n}=30 ; \mathrm{p}=0.000)$ which are reflected in positively perceived effectiveness of the leader by the employees, employees' satisfaction with the immediate superior and his/her leadership style and the encouragement of the subordinates by the managers to invest an additional effort into performing their work.

The authors used regression analysis to examine in more details the influence of the independent variable, i.e. social competencies of manager on the dependent variable, i.e. leadership outcomes.

Table 2: Model Summary

\begin{tabular}{|c|c|c|c|c|c|c|c|c|c|}
\hline & & & & & \multicolumn{4}{|c|}{ Change Statistics } \\
\cline { 6 - 10 } Model & $\mathrm{R}$ & $\begin{array}{c}\mathrm{R} \\
\text { Square }\end{array}$ & $\begin{array}{c}\text { Adjusted } \\
\text { R Square }\end{array}$ & $\begin{array}{c}\text { Std. Error of the } \\
\text { Estimate }\end{array}$ & $\begin{array}{c}\text { R Square } \\
\text { Change }\end{array}$ & F Change & $\mathrm{df1}$ & $\mathrm{df2}$ & $\begin{array}{c}\text { Sig. F } \\
\text { Change }\end{array}$ \\
\hline 1 & $.724^{\mathrm{a}}$ & .524 & .507 & .625042623106816 & .524 & 30.825 & 1 & 28 & .000 \\
\hline
\end{tabular}

Source: Author's calculation

Table 3: Anova test for regression model

\begin{tabular}{|l|l|r|r|r|r|r|}
\hline \multicolumn{2}{|l|}{ Model } & \multicolumn{1}{|c|}{$\begin{array}{c}\text { Sum of } \\
\text { Squares }\end{array}$} & \multicolumn{1}{c|}{ df } & Mean Square & F & Sig. \\
\hline \multirow{3}{*}{1} & Regression & 12.043 & 1 & 12.043 & 30.825 & $.000^{\mathrm{b}}$ \\
\cline { 2 - 7 } & Residual & 10.939 & 28 & .391 & & \\
\cline { 2 - 7 } & Total & 22.982 & 29 & & & \\
\hline
\end{tabular}

Source: Author's calculation

Based on Table 2 and Table 3 , it can be concluded that the model is statistically significant $(\mathrm{F}=30.825 ; \mathrm{Df}=1.28 ; \mathrm{p}<0.01$, , and that the independent variable (social competence) explains $52.4 \%$ of the variance of the dependent variable, i.e. leadership outcomes.

Table 4: Regression Model Coefficients

\begin{tabular}{|c|c|c|c|c|c|c|c|}
\hline \multirow{2}{*}{\multicolumn{2}{|c|}{ Model }} & \multicolumn{2}{|c|}{ Unstandardized Coefficients } & \multirow{2}{*}{$\begin{array}{l}\begin{array}{l}\text { Standardized } \\
\text { Coefficients }\end{array} \\
\text { Beta }\end{array}$} & \multirow{2}{*}{$\mathrm{t}$} & \multirow{2}{*}{ Sig. } & \multirow{2}{*}{ VIF } \\
\hline & & B & Std. Error & & & & \\
\hline \multirow{2}{*}{1} & (Constant) & -2.080 & 1.068 & & -1.948 & .061 & \\
\hline & AVR_SC & 1.615 & .291 & .724 & 5.552 & .000 & 1.000 \\
\hline
\end{tabular}

Source: Author's calculation 
Based on Table 4, which shows the coefficients of the regression model, the following conclusions can be drawn: the assumption of no multilinearity is not compromised, since the factor of increasing variance ( $\mathrm{VIF}=1$ ) is less than 10 (Pallant, 2017, p. 155), or less than 3 (Hair et al., 2019, p. 11). The results show that managers' social competencies have a statistically significant positive predictive effect $(\mathrm{V}=0.724 ; \mathrm{p}=0.000)$ on leadership outcomes. Possession of a higher level of social competencies (social awareness and relationship management) is associated with better leadership outcomes reflected in positively perceived leaders' effectiveness, employees' satisfaction with the leaders and the leaders' ability to encourage employees to put an extra effort into doing their job.

Based on the presented data, the conclusion is drawn that the hypothesis ,Social competenciesof manager are positively related to leadership outcomes (extra effort, effectiveness, and satisfaction)" was confirmed.

\section{Conclusion}

In modern business conditions, managers are expected to, in addition to the necessary professional competencies, also possess a certain level of emotional intelligence. A manager who has emotional and social competencies behaves like a leader and has the ability to influence his employees, by creating an adequate work climate, a climate of mutual trust that motivates employees to progress, develop, learn, believe in themselves, and achieve more than they think they could.

Emotionally intelligent managers or leaders create such an organizational climate that encourages the employees to put an extra effort and realize their potential. In a work atmosphere in which employees are satisfied and perceive their superiors as effective leaders, a higher degree of work engagement is encouraged, which is extremely important today, and will become even more important in the future.

Based on the available data and analysis using the above quantitative procedures, it can be concluded that there is a statistically significant cerrelation between the level of managers' social competencies and leadership outcomes. Emotional intelligence, especially social competencies, represents an extremely important factor that contributes to superior leadership outcomes.

Contribution of this research is reflected in connecting emotional intelligence (social competencies) and the outcome of leadership, which has been poorly researched so far, especially when it comes to our country. The limitation of the study is the size of the sample, so the authors' proposal for future research is to increase the sample and to examine whether emotional or social competencies have a greater impact on leadership outcomes.

\section{References}

Abraham, R. (1999). Emotional intelligence in organizations: A conceptualization. Genetic, Social, and General Psychology Monographs, 125(2), 209.

Ashkanasy, N. M., Härtel, C. E. J., \& Zerbe, W. J. (2000). Emotions in the work place: Theory, research, and practice. 
Bar-On, R. (1997). Bar-On Emotional Quotient Inventory (EQ-i). Technical Manual, Toronto, Canada: Multi-Health Systems.

Bartram, T., \& Casimir, G. (2007). The relationship between leadership and follower in-role performance and satisfaction with the leader. Leadership \& Organization Development Journal. 28(1), 4-19.

Bass, B. M., \& Avolio, B. J. (1997). Full range leadership development: Manual for the Multifactor Leadership Questionnaire. Mind Garden.

Berber, N., Slavić, A., Miletić, S., Simonović, Z., \& Aleksić, M. (2019). A Survey on Relationship between Leadership Styles and Leadership Outcomes in the Banking Sector in Serbia. Acta Polytechnica Hungarica, 16(7), 167-184.

Boyatzis, R. E. (2019). Emotional Intelligence and Its Measurement. In Oxford Research Encyclopedia of Business Management, 1-22.

Cooper, R.K. (1997). Applying emotional intelligence in the workplace. Training and Development 51(12), 31-38.

Dabke, D. (2016). Impact of leader's emotional intelligence and transformational behavior on perceived leadership effectiveness: A multiple source view. Business Perspectives and Research, 4(1), 27-40.

Emmerling, R.J. and Boyatzis, R.E. (2012). Emotional and social intelligence competencies: cross cultural implications. Cross Cultural Management: An International Journal, 19(1), 4-18.

Gardner, L., \& Stough, C. (2002). Examining the relationship between leadership and emotional intelligence in senior level managers. Leadership \& organization development journal, 23 (2), 68-78.

Goleman D. (1995). Emotional intelligence. New York: Bantam Books;

Goleman, D. (1997). Emocionalna inteligencija. Zagreb: Mozaik knjiga.

Goleman, D. (1998). Working with Emotional Intelligence. New York: Bantam books, p. 31;

Goleman, D. (2004). What makes a leader?. Harvard business review, 82(1), 82-91.

Guerin, D. W., Oliver, P. H., Gottfried, A. W., Gottfried, A. E., Reichard, R. J., \& Riggio, R. E. (2011). Childhood and adolescent antecedents of social skills and leadership potential in adulthood: Temperamental approach/withdrawal and extraversion. The Leadership Quarterly, 22(3), 482-494.

Hair, J.F., Risher, J.J., Sarstedt, M., \& Ringle, C.M. (2019). When to use and how to report the results of PLS-SEM. European Business Review, 31(1), 2-24.

Hay Group (2011). Emotional and social competences inventory (ESCI) - A user guide for accredited practionares.

Kerr, R., Garvin, J., Heaton, N., \& Boyle, E. (2006). Emotional intelligence and leadership effectiveness. Leadership \& Organization Development Journal, 27(4), 265-279.

Jawahar, I. M. (2006). An investigation of potential consequences of satisfaction with appraisal feedback. Journal of Leadership \& Organizational Studies, 13(2), 1428. 
Jelača, M. S., Bjekić, R., \& Leković, B. (2016). A proposal for research framework based on the theoretical analysis and practical application of MLQ questionnaire. Economic Themes, 54(4), 549-562.

Mayer, J. D., Caruso, D. R., \& Salovey, P. (2016). The ability model of emotional intelligence: Principles and updates. Emotion Review, 8(4), 290-300.

Mayer, John D. \& Salovey. P(1997). What is emotional intelligence.” P. Salovey. \& D. Sluyter. Emotional Development and Emotional Intelligence: Educational Implications (2010): 3-34.

McClelland, D. C. (1998). Identifying competencies with behavioral-event interviews. Psychological science, 9(5), 331-340.

Nabih, Y., Metwally, A. H., \& Nawar, Y. S. (2016). Emotional intelligence as a predictor of leadership effectiveness. The Business \& Management Review, 7(5), 133-142.

Pallant, J. (2017). SPSS priručnik za preživljavanje, 6th edition (translation): Mikroknjiga, Beograd.

Palmer, B., Walls, M., Burgess, Z., \& Stough, C. (2001). Emotional intelligence and effective leadership. Leadership \& Organization Development Journal, 22(1), $5-10$.

Petrides, K. V., \& Furnham, A. (2000). On the dimensional structure of emotional intelligence. Personality and individual differences, 29(2), 313-320.

Petrides, K. V., Pita, R., \& Kokkinaki, F. (2007). The location of trait emotional intelligence in personality factor space. British journal of psychology, 98(2), 273-289.

Riggio, R. E. (2010). Before emotional intelligence: Research on nonverbal, emotional, and social competences. Industrial and Organizational Psychology, 3(2), 178-182.

Rubin, R.S., Munz, D.C. and Bommer, W.H. (2005). Leading from within: the effects of emotion recognition and personality on transformational leadership behaviour. Academy of Management Journal, 48 (5), 845-858.

Szabó, S., Slavić, A., \& Berber, N. (2019). Coaching and its effects on individual and organizational performances in Central and Eastern Europe. Anali Ekonomskog fakulteta u Subotici, (41), 67-80.

Salovey, P., \& Mayer, J. D. (1990). Emotional intelligence. Imagination, cognition and personality, 9(3), 185-211.

Sadeghi, A., \& Pihie, Z. A. L. (2012). Transformational leadership and its predictive effects on leadership effectiveness. International Journal of Business and Social Science, 3(7), 186-197.

Seal, C. R., Boyatzis, R. E., \& Bailey, J. R. (2006). Fostering emotional and social intelligence in organizations. Organization Management Journal, 3(3), 190-209.

Strugar-Jelača, M. (2018). Redefining the management roles: Response to digital networking and access to a large amount of information. Strategic Management, 23(2), 42-49. 
Strukan, E., Terek, E., \& Nikolić, M. (2019). Impact of leadership on interpersonal trust at work in enterprises in Bosnia and Herzegovina. Journal of Engineering Management and Competitiveness (JEMC), 9(1), 48-59.

Schaap, P., \& Coetzee, C. (2005). The relationship between leadership behaviour, outcomes of leadership and emotional intelligence. SA Journal of Industrial Psychology, 31(3), 31-38.

Tasić, I., Merdović, M., Jankov, J., Nikolić, M., Terek, E., \& Jovanović, Z. (2020). Leadership, LMX and teaching process quality in primary schools. Anali Ekonomskog Fakulteta U Subotici, 56(43). Retrieved from https://anali.ef.uns. ac.rs/index.php/AnnalsEFSU/article/view/37

Van Oosten, E. B. (2013). The impact of emotional intelligence and executive coaching on leader effectiveness (Doctoral dissertation, Case Western Reserve University).

Vujić, D., Novaković, S., Maksimović, M., \& Karabašević, D. [2019]. The role of the leader in empowering and supporting employees towards sustainable development. Vojno delo, 71(5), 117-125.

Wang, G., Oh, I. S., Courtright, S. H., \& Colbert, A. E. (2011). Transformational leadership and performance across criteria and levels: A meta-analytic review of 25 years of research. Group \& organization management, 36(2), 223-270.

Webb, K. S. (2008). Creating satisfied employees in Christian higher education: Research on leadership competencies. Christian Higher Education, 8(1), 18-31.

Yost, C. A., \& Tucker, M. L. (2000). Are effective teams more emotionally intelligent? Confirming the importance of effective communication in teams. Delta Pi Epsilon Journal, 42(2), 101. 
